\title{
Measuring Students' Knowledge Level of Life Insurance: A Case on the Students of the Department of Insurance and Risk Management at the Dumlupinar University, Turkey
}

\author{
Res. Asst. Özer Bakar
}

Dumlupinar University, School of Applied Sciences, Department of Insurance and Risk Management, Turkey

\author{
Asst. Prof. Yavuz Soykan \\ Dumlupinar University, School of Applied Sciences, \\ Department of Insurance and Risk Management, Turkey \\ Teac. Asst. Burcu Acar \\ Dumlupinar University, School of Applied Sciences, \\ Department of Insurance and Risk Management, Turkey
}

Doi: 10.2478/jesr-2018-0009

\begin{abstract}
Life insurance is a type of insurance that protects individuals or their relatives who are left behind after death or permanent injury. Although it is quite different from the diversity in the world, life insurance in Turkey, which also allows accumulation with providing death benefit, contribute to the tendency of people to save money. One of the reasons for slower development in life insurances in Turkey compared to the countries in the world stems from the education in the field of insurance. Indicators such as insufficient number of institutes and experts in the field and low ratio of insurance literacy are the outcomes of this inadequate education system. Hence, lack of education is directly connected with the level of students' knowledge. The aim of this study, in which a cross-tabulated survey is used, is to measure the undergraduates' knowledge level of basics of life insurance at the department of Insurance and Risk Management in Dumlupinar University. Results show that students who are taking education at the Dumlupinar University at the department of Insurance and Risk Management, have very low knowledge about basic life insurance. This study is important in determining the knowledge level of the students who will be in the insurance sector in the future and who will have an individual relationship with the customers.
\end{abstract}

Keywords: Life Insurance, Cross-sectional Survey, Knowledge Level

\section{Introduction}

Life insurance is designed to ensure that income earners are guaranteed both their own and their families' lives, as well as their children's growth and economic independence (Akmut, 1980, 11).

Important factors in the failure of development of life insurance in Turkey include inflationist pressure, insufficient knowledge of the life insurance of the society, insufficient qualified and skilled staff, attitudes and behavior of insurance companies and distrust created by companies seeking to get more shares from unfair competition (Erdoğan, 2015, 3). 
The university education shapes the characteristics of the students in their workplace. Especially it supports improvement of the innovativeness, intellectual simulation and cooperation capabilities of the students (Brenner et al., 1991, 9). On the other hand, insurance education plays a major role in the development of the insurance industry as well as in individuals' selfimprovement. Better education can meet the needs of the industry's well-qualified staff, those welltrained staff will summarize the need of an insurance product to the society, so the insurance industry will grow with higher rate of insurability.

According to Dorfman (1998), the study of insurance can play a significant role in achieving the general goals of a broad-based undergraduate education and insurance is a way to accomplish the following goals:

- To encourage critical thinking, including moral and ethical reasoning

- To aid understanding human behavior

- To integrate knowledge across the business curriculum including marketing, finance, accounting, management systems

Each of the above conditions is necessary and important for insurance education. Questions such as "Can the capitalist society survive without a private insurance system?", "Should health insurance be provided by the state?", "Who should intervene in the premiums that cannot be socially accepted?" can be answered when critical thinking, logical analysis and ethics are known. Human behavior plays an important role in the hedging and avoidance of risk. Also, financial planning or risk management cannot be done without knowing human behavior. Insurance cannot be taught without economics, mathematics and law. Learning basic insurance information such as claims and premium calculations, investments of insurance companies and demand for indemnity is the most basic function of insurance education (Dorfman, 1998, 15).

Insurance plays an important role in meeting the need for trust in society. When people are exposed to the risk, they must feel that insurance protection works, but this depends only if people are informed truly before the insurance product is sold. This can be achieved only with taking qualified education in order to work as an insurance professional. In this study, it is aimed to measure basic life insurance knowledge levels of students who have undergraduate insurance education at Dumlupinar University.

\section{Life Insurance in Turkey}

Life insurance is such a contract that the insurer withholds the obligation to pay a certain amount of money to the insured or to beneficiary under the condition of the insurer dies in certain period or survives on the end of the date of that certain period in the contract (Ulaş, 2009, 9).

Life insurance system is based on a contract that protects policyholder and his family members against financial problems when various risks occur during the policy term such as death and disability of person. When the risk occurs, the benefit, which is the amount determined in the contract, is given to beneficiaries. The policyholder is responsible for paying premiums that are calculated according to coverage amount (Yakan, 2013).

There are various types of life insurance products, such as life insurance for banking products which pays the credit risk, and education insurance which pays the cost of education of policyholder's children. Certainly, the number of similar examples that provide financial protection after death or permanent injury, for the beneficiaries as common feature can be increased. Life insurance in Turkey can be divided into two groups if it is needed to be classified. These are riskweighted life insurance and cumulative (permanent) life insurance. Unlike the distinctions in the world, in Turkey, risk-weighted life insurance products are called term life insurance when applied for a certain period of time, and it is called full life insurance or life-long insurance when they cover the whole life. Risk-weighted life insurance products give protection for beneficiaries only when the death of insured occurs. In addition to the death benefit, the cumulative life insurance provides, as a guarantee, the remaining portion of the risk premium which is invested as long as the insured is alive at the end of a certain period. This type of insurance is also called mixed insurance since it provides both life and death coverage.

Another cover in life insurance in addition to death benefit is a disability guarantee that 
provides coverage against financial loss in case of disability. In the case of full or partial permanent disability resulting from diseases or accidents, the indemnity determined in the policy is paid within certain rates. In practice, it is added to the insurance policy by paying an additional premium. The disability rates in Turkey are determined by the government. In case of permanent disability, the disability rate is multiplied by the indemnity and the insured is paid.

Life insurance premiums vary according to age, gender and the amount of indemnity requested. Since the risk-weighted life insurance policy that only provides death benefit has a fixed cost, its premium is lower than the cumulative life insurance policy premium that provides accumulation. Conversely, indemnity in cumulative life insurance policies is lower than in riskweighted life insurance policies which can be purchased with the same premium. The reason is that a portion of the premium in cumulative life insurance policy is to be invested.

\section{Knowledge Level}

The concept of knowledge comes from the Latin "informato" and is used in the sense of "giving form", "shaping" and "giving news". Knowledge is generally defined as "intellectual product" or "learned thing" obtained through thinking, judging, reasoning, reading, observation and experimentation. Information, in this sense, is data that has been processed through a specific process, meaningful to the owner, or assumed to have a strategic prescription in managerial decision making (Öğüt, 2003, 9).

Economic necessities require effective use of human resources and make all young people ready for business life. Living in an information-technology intensive society and getting better working opportunities will be among the most important goals of youth in the new period of life. It is schools that are responsible for presenting these opportunities to the educated young population. Developing a school identity that is sensitive to changes in the environment, to be able to make the necessary decisions quickly and accurately, and to be able to reflect the needs of change in programs as soon as possible have become the basic requirements (Doğan, 1997, 7).

The usual way of teaching at school is often limited to the transfer of a certain amount of knowledge to students and to their memorization. The program does not include any content that enhances students' thinking and problem-solving skills. The greatest mental activity of a student who does not have the ability to think is to recall the knowledge he has stored, but not knowing how and where to use it (Özden, 2002, 18-19).

The main role of teachers in the information society is to teach by taking the student to the center of the learning environment, letting him to learn how to access the information and how to benefit from it (Numanoğlu, 1999, 347). Educational change in the global information society refers to the training of students who are able to adapt to the new turn and to change in educational programs (Tezcan, 2002, 57).

The weakness of the technical knowledge acquired in the university will lead to the lack of theoretical and practical knowledge of young people who will create the workforce. This also undoubtedly will have a negative impact on the insurance sector, which has not yet gained credibility in Turkey. Failure to provide accurate and complete information to customers seeking to purchase an insurance product may leave insured people unprotected after the insured die. As a result, individuals' belief in the insurance sector is shaken and they try to protect themselves in different ways.

\section{Data and Results}

In this cross-sectional study, it was aimed to measure the level of basic knowledge of life insurance of students belong to the Dumlupınar University of the department of Insurance and Risk Management. SPSS (Version 11.5) program was used in the analysis of the data. The t-test was used to investigate the differences of the students according to gender, type of education and work experience, while Anova test was used when the differences between the classes were investigated. 
Table 1: Descriptive Statistics Related To Participants

\begin{tabular}{|l|l|c|c|c|}
\hline & & Number & Percentage & Total \\
\hline \multirow{2}{*}{ Gender } & Male & 64 & $39,75 \%$ & \multirow{2}{*}{161} \\
\cline { 2 - 4 } & Female & 97 & $60,25 \%$ & \multirow{2}{*}{161} \\
\hline \multirow{2}{*}{ Education Type } & Formal Education & 104 & $64,60 \%$ & \multirow{3}{*}{161} \\
\cline { 2 - 4 } & Evening Education & 57 & $35,40 \%$ & \\
\hline \multirow{3}{*}{ Grade } & 2nd & 64 & $39,75 \%$ & \multirow{2}{*}{161} \\
\cline { 2 - 4 } & 3rd & 58 & $36,03 \%$ & $24,22 \%$ \\
\cline { 2 - 4 } & 4 th & 39 & $12,42 \%$ & \\
\hline \multirow{2}{*}{ Working Experience } & Experienced & 20 & $87,58 \%$ & \\
\cline { 2 - 4 } & Non-experienced & 141 & & \\
\hline
\end{tabular}

Table 1 shows the descriptive statistics of participants. Students are classified by gender, type of education, grade and work experience. In this study which 161 students attended, it was seen that 64 were male and 97 were female. 104 students receive normal education while 57 students are evening education students. In the first year of Insurance and Risk Management, there are not any courses related to insurance therefore, the questionnaire not applied to the first year students (freshmen), so there are 64 students in the second, 58 in the third, and 39 in the fourth grade. There are 20 work experience and 141 non-work experience students. Work experienced student means a student is working as their education continues or worked before being student in insurance sector.

\subsection{Knowledge Level of Students}

In this study, the survey questions that Ramchander (2016) used in studying consumer's basic knowledge of life insurance were adapted for Turkey.

Table 2: Number of Responses per Questions

\begin{tabular}{|c|c|c|c|c|c|c|}
\hline \multirow[b]{2}{*}{ 1) } & \multirow{2}{*}{\begin{tabular}{|l|} 
Questions \\
$\begin{array}{l}\text { I experience difficulty in telling the difference between different life } \\
\text { insurance products }\end{array}$ \\
\end{tabular}} & \multicolumn{2}{|c|}{ Agree } & \multicolumn{2}{|c|}{ Disagree } & \multirow{2}{*}{\begin{tabular}{|c|} 
Tota \\
161
\end{tabular}} \\
\hline & & 59 & $36,65 \%$ & 102 & $63,35 \%$ & \\
\hline 2) & $\begin{array}{l}\text { A term life insurance provides death coverage until whichever day of } \\
\text { death of the insured person }\end{array}$ & 95 & $59,01 \%$ & 66 & $40,99 \%$ & 161 \\
\hline 3) & $\begin{array}{l}\text { I consider my knowledge of basic life insurance level; good (above } \\
\text { average) }\end{array}$ & 86 & $53,42 \%$ & 75 & $8 \%$ & 161 \\
\hline 4) & A term life insurance cover ends after a specified period & 119 & & 42 & & 161 \\
\hline 5) & A life insurance product may include a & 88 & $66 \%$ & 73 & $34 \%$ & 161 \\
\hline 6) & $\begin{array}{l}\text { The cumulative life insurance product is worth more than the risk- } \\
\text { weighted life insurance product which can be purchased with the } \\
\text { same premium }\end{array}$ & 75 & $46,58 \%$ & 86 & $53,42 \%$ & 161 \\
\hline 7) & A cumulative life cover cannot be used as an investment tool & 53 & $32,92 \%$ & 108 & $67,08 \%$ & 161 \\
\hline 8) & $\begin{array}{l}\text { The premium of the cumulative life insurance product is much less } \\
\text { than the premium of the risk weighted life insurance product which } \\
\text { provides the same death benefit }\end{array}$ & 88 & $54,66 \%$ & 73 & $45,34 \%$ & 161 \\
\hline 9) & There is no maximum limit of the disability benefit & 49 & $30,43 \%$ & 112 & $69,57 \%$ & 161 \\
\hline 10) & The maximum disability cover is regulated by the law & 115 & $71,43 \%$ & 46 & $28,57 \%$ & 161 \\
\hline
\end{tabular}

Table 2 shows the number of answers (yes-no) whether students participate in the questions. The questionnaire contains 10 questions, but 5 key questions were asked in two different ways. For example, Question 1 related to Question 3, Question 2 related to Question and so on. The aim is to control participants responding to questions in the same way, and to prevent participants answer to multiple choice questions randomly.

Approximately $36 \%$ of the students stated that they had difficulty in describing the differences between life insurance products. However, about $47 \%$ of the students have argued that their 
knowledge about life insurance products is not good (above average). Further results show that they think that they know more than they actually do.

The term life insurance is a product that the beneficiary have right to receive indemnity after the insured lost his life in a certain period of time. Nevertheless, about $59 \%$ of the students think that the person who bought this product has the right to have death benefit at any time. Approximately $26 \%$ of the students responded incorrectly by not participating in the statement that the term life insurance had expired at the end of a certain date. The big difference between the answers to the two expressions may indicate that the students did not understand these questions.

The students who think that the term life insurance product can also be used for accumulation are about $55 \%$ of all the students who participated in the survey. The percentage of students who do not participate in the statement that the cumulative life insurance cannot be used as an investment instrument is about $67 \%$. Nearly half of the students seem to have answered this question correctly. Cumulative life insurance products in Turkey are also under the term life insurance policy. Cumulative life insurance products provide mortality death benefit within a certain period besides life benefit which means in the case of being alive of the individual who receives this product at the end of the same specific period.

The value of a cumulative life insurance that can be purchased with the same premium is less than a risk-weighted life insurance that does not have a function of accumulation but only death coverage. The reason is that only the risk premium is calculated for the risk-weighted life insurance because it provides only death benefit within a certain period. Since the probability of being alive at the end of a certain period of time necessitates calculation of the accumulation factor, the risk premium will be smaller to obtain the same premium. This lower risk premium will result in a lower benefit. Approximately $53 \%$ of the students have made the right choice by not participating in the statement of the cumulative life insurance, which can be purchased with the same premium, much more value than the risk-weighted life insurance. At the same time, the premium of the cumulative life insurance that provides the same death benefit is higher than the premium of the risk weighted life insurance. The students who think in this direction are about $45 \%$ of all the students who participated in the survey.

Permanent disability benefits in life insurance products are determined in Turkey by law. The disability rates are multiplied by the guarantee of the insurance product and the insured is paid. When this rate is $100 \%$, the full amount stated in the policy has to be paid. Approximately $71 \%$ of the students participated in the statement of benefits are determined by the state, while about $70 \%$ of the students who participated in the survey gave the correct answer without participating in the statement that there is no upper limit of disability guarantee.

The right or wrong numbers given to the question above may not exactly reflect the truth. This is because the participant can respond correctly to one of the cross-questions while responding wrongly to the other. This affects the consistency of the answers given to the questions in negative way. Therefore, the number of correct respondents to both cross-questions is calculated.

Table 3: Correct Responses Given by the Participants for Cross-Tabulated Questions

\begin{tabular}{|c|c|c|}
\hline & Number & Percent \\
\hline $\begin{array}{l}\text { A term life insurance provides death coverage until whichever day of death of the } \\
\text { insured person / A term life insurance cover ends after a specified period }\end{array}$ & 53 & $32,92 \%$ \\
\hline $\begin{array}{l}\text { A term life insurance product may include a savings element / A cumulative life } \\
\text { cover cannot be used as an investment tool }\end{array}$ & 73 & $45,34 \%$ \\
\hline $\begin{array}{l}\text { The cumulative life insurance product is worth more than the risk-weighted life } \\
\text { insurance product which can be purchased with the same premium / The premium } \\
\text { of the cumulative life insurance product is much less than the premium of the risk } \\
\text { weighted life insurance product which provides the same death benefit }\end{array}$ & 34 & $21,12 \%$ \\
\hline $\begin{array}{l}\text { There is no maximum limit of the disability benefit / The maximum disability cover is } \\
\text { regulated by the law }\end{array}$ & 84 & $52,17 \%$ \\
\hline
\end{tabular}

Table 3 shows the number of correct answers of respondents in both cross-questions. According to table 3 , it can be said that the response rates to the question pairs are low. The lowest rate belongs 
to the pair of questions that include the value of the life insurance products. $21,12 \%$ of the students answered this questions correctly. That means a large majority of students do not know the premium calculation of life insurance products and cannot distinguish how premiums will change in different benefits in different life insurance products. The lack of mathematical insurance courses in the curriculum and experted faculty members is the cause of this problem. The highest rate belongs to the pair of questions, which includes the upper limit of the disability guarantee that $52.17 \%$ of the students responded correctly. But also this means that one of the two learners does not know the basic life insurance legislation.

\subsection{Knowledge Score and the Real Knowledge Score}

This questionnaire contains 10 expressions, but the first and third expressions verbally express how much the student know about life insurance so they are not question. The knowledge score was calculated by giving 1 point for each of the other 8 questions in the questionnaire of the basic life insurance knowledge level. However, since this score does not take into account the answer given randomly or whether or not questions can be understood, real knowledge scores were calculated by taking into account the consistency of answer.

Both scores are out of 8 points. According to the knowledge score, each true question is 1 point. For the real knowledge score; those who answered correctly to the two questions received 2 points, those who gave wrong answers to either or both received 0 points from that cross-tabulated questions. Knowledge levels refer for very low is between 0-2 points, low for 3-4 points, medium for 5-6 points and high for 7-8 points.

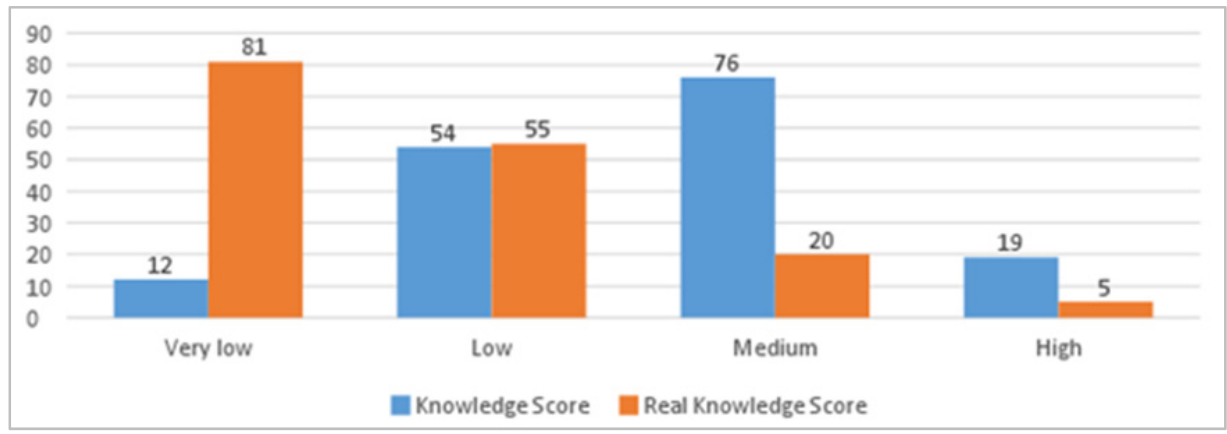

Figure 1: Frequency of the Knowledge Score and the Real Knowledge Score

Figure 1 shows the frequencies for the knowledge scores. In the scale of knowledge score, the number of students with very low knowledge level is 12, the number of students with low knowledge level is 54 , the number of students with medium knowledge level is 76 and the number of students with high knowledge level is 19 . However, in the scale of real knowledge score, the number of students with a very low knowledge level is 81 , the number of students with a low knowledge level is 55 , the number of students with a medium knowledge level is 20 and the number of high level knowledge students is 5 . The big difference between the knowledge and the real knowledge scores shows that most of the students are inconsistent in the answers they gave or they could not understand the questions. According to the real knowledge scores, approximately $85 \%$ of students have very low or low basic life insurance knowledge.

\subsection{Differences Between Groups}

The knowledge score and real knowledge score were also calculated according to gender, type of education, work experience and the grade of students and statistically tested whether there is a difference between them. 
Table 4: Independent t Test about Knowledge Scores According to the Demographic Details

\begin{tabular}{|c|c|c|c|c|c|c|}
\hline & & \multicolumn{2}{|c|}{ Knowledge Score } & \multicolumn{2}{|c|}{ Real Knowledge Score } \\
\hline & & $\mathbf{N}$ & Mean & Sig. & Mean & Sig. \\
\hline \multirow[b]{2}{*}{ Gender } & Men & 64 & 4,8125 & \multirow[b]{2}{*}{0,750} & 3,1875 & \multirow[b]{2}{*}{0,008} \\
\hline & Women & 97 & 4,7320 & & 2,9278 & \\
\hline \multirow{2}{*}{ Education Type } & Formal & 104 & 4,8942 & \multirow{2}{*}{0,154} & 3,1538 & \multirow{2}{*}{0,649} \\
\hline & Evening & 57 & 4,5263 & & 2,8070 & \\
\hline \multirow{2}{*}{ Working Experience } & Yes & 20 & 5,0000 & \multirow{2}{*}{0,472} & 3,1000 & \multirow{2}{*}{0,606} \\
\hline & No & 141 & 4,7305 & & 3,0213 & \\
\hline
\end{tabular}

$p<0,05$

According to table 4 , the average knowledge score of males is 4,8125 and that of females is 4,7320 . But there was no significant difference between these averages statistically. When the real knowledge score is calculated, the male's real knowledge score is 3,1875 , which is greater than the female's real knowledge score of 2,9278 and this difference is statistically significant. It can be said that males have more knowledge about basic life insurance than females. There was no significant difference between education type and work experience in terms of both knowledge and real knowledge score. This means that the type of education and work experience cannot make a difference in students' basic knowledge level scores.

Table 5: Anova for Knowledge Scores According to the Grade of Participants

\begin{tabular}{|c|c|c|c|c|c|c|}
\hline \multicolumn{2}{|c|}{} & & \multicolumn{2}{c|}{ Knowledge Score } & \multicolumn{2}{c|}{ Real Knowledge Score } \\
\cline { 3 - 4 } \multicolumn{2}{|c|}{ Grade } & N & Mean & Sig. & Mean & Sig. \\
\hline & 2nd & 64 & 4,6563 & & 2,7813 & \multirow{2}{*}{0,433} \\
\cline { 2 - 4 } & 3rd & 58 & 4,8621 & 0,763 & 3,2414 & \\
\cline { 2 - 4 } & 4th & 39 & 4,7949 & & 3,1282 & \\
\hline
\end{tabular}

According to table 5 , no statistically significant difference was found between the grade of students in terms of both information score and real knowledge score.

\section{Conclusion}

This study is important in determining the level of knowledge of the students who will be in the insurance sector in the future and who will have an individual relationship with the customers and also important to prepare a better course curriculum related to life insurance to better understand life insurance products. Of course, this work should be developed by applying to all higher education institutions providing insurance education in the country and adding insurance stakeholders.

Results show that students who are taking education at the Dumlupinar University at the department of Insurance and Risk Management, have very low knowledge about basic life insurance. The one of the duties of the university, as an institution, is to educate individuals for the profession by conveying the knowledge to the students. This can only be done by preparing better curriculum and educating academic staff.

However, the level of knowledge that is tried to be measured by multiple choice questions can give misleading results. The real knowledge score obtained by preparing crossed-tabulated questions is the proof of this situation. This prevents students from responding to questions randomly. Further studies, the content of these questions can be expanded and compared with other departments in universities that offer insurance courses which have different curriculums.

Technological reforms must be made by adapting to the developing world and better education should be provided by using new teaching techniques. Instead of loading encyclopedic information, lessons should be followed by training programs that focus on deepening and critical thinking about topics and events. In the coming period the individual's success will depend on producing and using knowledge, and Universities are the biggest institutions that teach the individual how to use knowledge. 


\section{References}

Akmut, Ö. (1980). Hayat Sigortası. Ankara Üniversitesi Siyasal Bilgiler Fakültesi Yayınları, (447).

Brenner, O. C., Pringle, C. D., \& Greenhaus, J. H. (1991). Perceived Fulfillment of Organizational Employment Versus. Journal of Small Business Management, 29(3), 62.

Doğan, H. (1997). Mesleki ve teknik eğitimin yeniden yapılandırılması. Ankara Üniversitesi Eğitim Bilimleri Fakültesi Dergisi, 30(1), 1-26.

Dorfman, M. (1998). Introduction to Risk Management and Insurance, Prentice-Hall International. $6^{\text {th }}$ Edition. New Jersey.

Erdoğan, N. K. (2003). Farkıı Meslek Gruplarının Hayat Sigortasına Bakışı ve Bireysel Emeklilik Sigortasının Geleceği. Dumlupınar Üniversitesi Sosyal Bilimler Dergisi, 8(8).

Numanoğlu, G. (1999). Bilgi toplumu-eğitim-yeni kimlikler-II: Bilgi toplumu ve eğitimde yeni kimlikler. Ankara Üniversitesi Eğitim Bilimleri Fakültesi Dergisi, 32(1-2), 341-350.

Öğüt, A. (2003). Bilgi Çağında Yönetim (2. Baskı). Nobel Akademik Yayıncılık.

Özden, Y. (2000). Öğrenme ve Öğretme. (4. Baskı), Ankara: Pegem A Yayıncılık.

Ramchander, M. (2016). Measuring Consumer Knowledge of Life Insurance Products In South Africa. South African Journal of Business Management, 47(2), 67-74.

Tezcan, M. (2002). Küreselleşmenin eğitim boyutu. Eğitim Araştırmaları Dergisi, 6, 56-60.

Ulaş, I. (1997). Uygulamalı Can Sigortası Hukuku. Turhan Kitabevi Yayınları, Ankara.

Yakan, B. (2013). Bireysel Emeklilik ve Hayat Sigortaları Sistemlerinde Çapraz Satış Karar Destek Sistemi. Yayımlanmış Yüksek Lisans Tezi. Galatasaray Üniversitesi, İstanbul. 